\title{
An Agent-Based Model for Simulating Irrigated Agriculture in the Samambaia Basin in Goiás
}

\author{
Um Modelo Baseado em Agentes para Simulação de Agricultura Irrigada na Bacia do \\ Samambaia em Goiás
}

\author{
Guido Dutra de Oliveira ${ }^{1}$, Pedro Phelipe Gonçalves Porto², Conceição de Maria Albuquerque \\ Alves $^{2}$, Célia Ghedini Ralha ${ }^{1 *}$
}

\begin{abstract}
Agriculture is one of the main economic activities in Brazil. The intensive use of water for irrigated agriculture leads to water rise demand contributing to increase water stress. Agent-based models help assess this problem with promising applications entailing an organizing principle to inform us of how to view a real-world system and effectively build a model. In this work, agent-based modeling is applied to simulate water usage for irrigation in agricultural production in the Samambaia river basin in the municipality of Cristalina in the Goias state of Brazil. The use of real data enables analysis of resource availability in a scenario with high demand irrigation, allowing a greater understanding of the needs of the parties involved.

Keywords: agent-based modeling — agent-based simulation — irrigation — water resources

Resumo: A agricultura é uma das principais atividades econômicas no Brasil. O uso intensivo de água para agricultura irrigada acarreta o crescimento das demandas hídricas contribuindo para o aumento do stress hídrico. Modelos baseados em agentes ajudam a avaliar esse problema com aplicações promissoras envolvendo um princípio de organização para nos informar sobre como visualizar um sistema do mundo real e efetivamente construir um modelo. Neste trabalho foi aplicada a modelagem baseada em agentes para a simulação de uso de água para irrigação na produção agrícola da bacia do rio Samambaia no município de Cristalina no estado de Goiás no Brasil. O uso de dados reais viabiliza análise de disponibilização do recurso em um cenário com alta demanda para irrigação, permitindo um maior entendimento das necessidades entre as partes envolvidas. Palavras-Chave: modelagem baseada em agente — simulação baseada em agente — irrigação — recursos hídricos

${ }^{1}$ Computer Science Department, University of Brasília (UnB), Brasília - Distrito Federal, Brazil

${ }^{2}$ Civil Engineering and Environmental Department, University of Brasília (UnB), Brasília - Distrito Federal, Brazil

*Corresponding author: ghedini@unb.br

DOI: http://dx.doi.org/10.22456/2175-2745.107041 • Received: 30/08/2020 • Accepted: 08/02/2021

CC BY-NC-ND 4.0 - This work is licensed under a Creative Commons Attribution-NonCommercial-NoDerivatives 4.0 International License.
\end{abstract}

\section{Introduction}

Nowadays, water scarcity is among the main problems to be faced by society. Insufficient freshwater resources to meet human and environmental demands are considered a priority for global development. Although a vast number of environmental, economic, and engineering solutions have been proposed or implemented worldwide, the problem deserves continuous investigation to satisfy long-term average requirements $[1,2]$.

The population increase and intensive economic activities in water use lead to water stress. According to [3], the main use of water in terms of quantity in Brazil is irrigation, corresponding to $66.1 \%$ of the total consumption of $1,101 \mathrm{~m}^{3} / \mathrm{s}$ (annual average 2018). This use corresponds to the agricultural practice employing equipment and techniques to supply total or partial deficiency of water for the crops that vary according to each crop, type of soil, relief, climate, and other variables. Traditionally, irrigation allows supplementation of rainfall regime enabling cultivation in places with specific periods of drought as in the central region of Brazil.

One of the most used methods in irrigated agriculture corresponds to the central pivot. The activity or idleness of the areas irrigated by pivots is extremely dynamic throughout the year. Irrigation is of fundamental importance for better characterization of the water balance in the hydrographic basins. According to the new survey of agriculture irrigated by central pivots [4], it is currently estimated a total of approximately 7.3 million hectares of irrigated area in Brazil with a potential increase of 3.14 million hectares by 2030 (45\% expansion). In 2017 , there were 23,181 pivot points with $1,476,101$ hectares 
equipped for irrigation by central pivots, which corresponds to about $20 \%$ of the total irrigated area and $30 \%$ of the mechanized irrigated area. In this scenario, the three major irrigating municipalities in Brazil are Unaí and Paracatu (Minas Gerais state), and Cristalina (Goiás state), which form the largest pivot concentration with 2,558 pivot points occupying 191 thousand hectares.

The plantation's water demand increases in the dry season in the central region of the country, particularly in large irrigating municipalities such as Cristalina (Goiás), illustrated by Figure 1. The effective occupation rate (area effectively planted under the pivots) in this period is around 30 to $50 \%$ lower than in the rainy season, which reaches $70-98 \%$ when most of the water is supplied by precipitation.

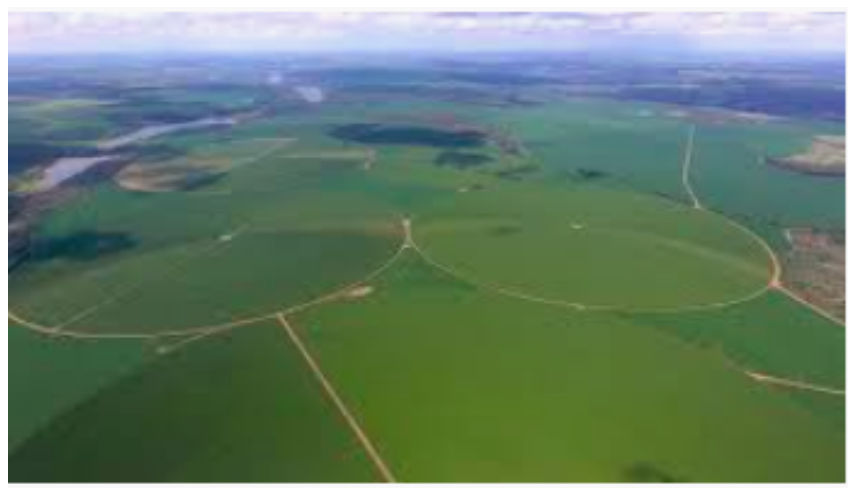

Figure 1. Irrigation pivots for agriculture.

The need for artificial application of water per hectare rises dramatically during the drought period. That coincides with the lower availability of water in rivers and reservoirs becoming a water management challenge. As a water resource engineering support discipline, computing can assist through mathematical modeling techniques [5], numerical analysis [6], instrumentation [7], geoprocessing [8], remote sensing [9], statistics [10], systemic analysis [11], as well as agent-based modeling applications $[12,13,14,15]$.

An agent-based model is not only an organizing principle but informs us of both how to view a real-world system and how to effectively build a model of that system. Agentbased modeling (ABM) systems can benefit from computational techniques that allow an adequate approach to treating complex systems, particularly involving anthropic action as socio-environmental phenomena. The use of ABM with simulation enables the analysis of results in a realistic way when compared to the application of more traditional techniques, such as simulation of discrete events [16], system dynamics [17], Monte Carlo method [18] and continuous systems simulation [19].

The main characteristic of the ABM is the focus on the agent as a fundamental unit, including the interaction with other individuals and with the environment, which makes complex applications possible with an emphasis on social and socio-environmental phenomena. ABM associated with computer simulation makes it possible to explore alternative scenarios and forecasts. This association promotes a greater understanding of the relationship between stakeholders and becomes a valuable tool for conflict resolution. The emergence of agent-based approaches implies two aspects of great interest as a more robust and better-based decision-making tool for real-world phenomena. It is considered a scientific research instrument that offers an alternative method to traditional induction and deduction. The dual utility - social and scientific - led to the popularization of the approach [20].

The case study uses the Samambaia river basin real data in the Cristalina municipality at Goias state in the centralwest region of Brazil. The climate in the region is considered tropical with a dry season (Aw type according to KöppenGeiger classification [21], having mild summers and winters, with reduced rainfall. The rainy season runs from October to April and, from May to October, the dry season occurs, with an average annual rainfall of $1,400 \mathrm{~mm}$. Since agriculture is the most representative socio-economic indicator in the municipal gross domestic product, representing approximately $40 \%$, the drought period can bring great damage to the region's economy [22].

Thus, this work applies ABM for the simulation of agriculture irrigated by pivots throughout the dry and rainy season with different crops (soy, corn, cotton, beans, potatoes, garlic, onions, tomatoes) in the Samambaia river basin. The agents in the model are represented by farmers that are the agricultural producers associated with specific regions on the simulation map. Farmers are objective oriented agents that consider expenses to choose the crops to be planted to maximize profit as described in Section 2.2.

Due to the high demand for irrigation water in the Cristalina municipality, the study carried out serves as a typical example of the challenge for water management in the country. This work focuses on three research questions (RQ):

- RQ1. What is the total water demand for agricultural production in the different sub-regions of the basin considering different periods of the year?

- RQ2. What is the equity generated by the producer?

- RQ3. What is the revenue per crop considering the influence of water scarcity scenarios?

The modeling of the basin was performed on the GAMA version 1.8 platform, using the GAML language. GAMA is an open-source development environment for spatially explicit agent-based modeling and simulation designed to support the definition of complex models with strong support for the spatial dimension [23]. The ODD (Overview, Design concepts and Details) modeling protocol [24, 25] was applied to improve the formulation of the agent-based model helping to make the theoretical foundations more understandable and reproducible.

The number and breadth of applications for ABM and simulation are truly remarkable and continue to grow [20]. There are many works that apply ABM to water resources 
analysis [26, 27, 28, 29, 30]. Also, the application of ABM to agriculture and irrigation have received attention worldwide [31, 32, 33]. According to our literature review, a few works applies ABM and simulation to agriculture in Brazil [34]. Particularly in large irrigating municipalities in the central-west region, one of the main irrigation hubs includes Cristalina (Goiás state). Cristalina provides more than 45 different products that go to the table of millions of Brazilians. Without irrigation, producers would be able to take a maximum of four products from the land. The Samambaia River basin is the most important for Cristalina agriculture. Around this river is a large part of the producers that use irrigation. But the past few years have been critical for this part of the cerrado with the little rain made rivers almost dry, affecting negatively the agricultural production [35]. Thus, this work fulfills the need for studies in the Cristalina municipality with agriculture production analysis using pivot irrigation.

The rest of the article is organized as follows. In Section 2, the materials and methods applied in the work are described. In Section 3, the case study in the Samambaia river basin is presented with the results of the simulations using two different scenarios. A brief discussion related to recent works is presented in Section 4. Finally, in Section 5, conclusions are presented and future work cited.

\section{Materials and Methods}

In this work, individual agents represent agricultural producers categorized by the number of irrigation pivots available for their production. For the development of the agent-based simulation model, some materials and methods were used such as a simulation platform (Section 2.1) and the ODD modeling protocol (Section 2.2).

\subsection{Simulation Platform}

There are several open-source agent-based modeling and simulation tools cited in the literature. Such tools vary from complete platforms to language extensions and frameworks. In this work, we considered some of the simulation tools being used for water resource management as presented in the researches of Section 4.

- the Common-pool Resources and Multi-Agent Systems

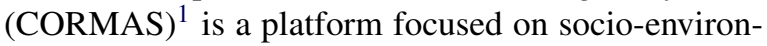
mental models, particularly models of renewable resource systems [36]. CORMAS is based on the Visual Works platform for developing programs in the Smalltalk language. It focuses on the Companion Modeling Approach that consists of the use of the model by the interested parties themselves, as a Role Playing Game tool, aiming to provide those involved with a greater understanding of the system of which they are part.

\footnotetext{
${ }^{1}\langle$ http://cormas.cirad.fr/indexeng.htm $\rangle$
}

- the NetLogo ${ }^{2}$ is an open-source agent-based simulation environment that uses a modified version of the Logo programming language. It has a generic scope of application and it is one of the most popular agentbased modeling and simulation tools [37]. The NetLogo was developed in the Scala and Java languages by Uri Wilensky at the Center for Connected Learning and Computer-Based Modeling at Northwestern University, Illinois, USA.

- the Repast Simphony ${ }^{3}$ is a widely used free and opensource cross-platform agent-based modeling and simulation toolkit. The Repast has multiple implementations in several languages and built-in adaptive features, such as genetic algorithms and regression. The geographic information system is provided through geography projections that, like the other spatial projections in Repast Simphony, correlate the agents to positions in space. The Repast was originally developed by David Sallach, Nick Collier, Tom Howe, Michael North, and others at the University of Chicago, but it has been under continuous development for over 15 years [38].

- the Multi-Agent for EnvironmentaL norms Impact Assessment (MAELIA) ${ }^{4}$ platform emerged from the GAMA platform and has a smaller scope restricted to models of agriculture and management of natural resources [39]. MAELIA provides a software architecture to address questions about the interaction between agricultural activity, the dynamics of agricultural landscapes, and the management of natural resources.

- the GAMA ${ }^{5}$ platform is an integrated development environment (IDE) for building spatially explicit agentbased models, especially focused on modeling socioenvironmental systems [40].

Although many modeling platforms ease the work of the modelers, like CORMAS, NetLogo, Repast, there are differences in how they assist in the decision-making process. In [23], the authors claim that the main reason lies in the lack of implication of stakeholders in the model design and exploration (simulation) processes. An approach that can overcome this difficulty is participatory modeling since it aims at using modeling in support of a decision-making process involving stakeholders [41]. The GAMA modeling and simulation platform has participatory tools integrated within, that allows to build models graphically and develop distributed serious games in a simple way adapted to modelers who are not experts in computer science.

The GAMA platform was chosen to develop this project. GAMA has a high-level language specifically for agent-based modeling (GAML) coded in Java that supports the geographic information system and creation of graphical interfaces with Open Graphics Library (OpenGL), which works on several

\footnotetext{
${ }^{2}\langle$ https://ccl.northwestern.edu/netlogo/ $\rangle$

${ }^{3}\langle$ https://repast.github.io/ $\rangle$

${ }^{4}\langle$ http://maelia-platform.inra.fr $\rangle$

${ }^{5}$ https://gama-platform.github.io/wiki/Home $\rangle$
} 
platforms to render 2D and 3D vector graphics. GAMA provides modelers with native integration of GIS data [42]. The project code and documentation are available in the research group repository ${ }^{6}$.

\subsection{ODD Protocol}

The ODD protocol was first published in 2006 to standardize the published descriptions of individual-based and agentbased models not only in ecology but also in many other disciplines dealing with complex systems made up of autonomous entities [24]. The primary objectives were to make model descriptions more understandable and complete, thereby making individual and agent-based models less subject to criticism for being irreproducible.

According to [25] ODD improves the rigorous formulation of models and helps make the theoretical foundations of large models more visible. We used ODD to standardize the description of the model, facilitate communication and facilitate reproduction. The ODD protocol includes in the model description three categories (Overview, Design concepts and Details) which are subdivided into seven elements: Purpose, State variables and scales, Process overview and scheduling, Design concepts, Initialization, Input, and Submodels. This work's agent-based model description using the ODD protocol is presented in Sections 2.2, 2.2 and 2.2.

\section{ODD 1 - Overview}

Purpose In this work, the use of water-related to agricultural activity in the Samambaia river basin was modeled, to investigate how producers choose crops according to available water resources. In particular, we want to explore scenarios of water scarcity and their influence on the behavior of producers by analyzing the wealth generated by the producer category and revenue by culture.

State variables \& scales The model includes six entities or species, as follows:

- Global - represents the world or the agent simulation environment, being spatially characterized by the Samambaia river basin divided into three sub-basins: Rato stream, northern Samambaia, and southern Samambaia.

- Farmer - represents the agricultural producer being associated with a contiguous region of the map with a certain number of central pivots. The main activity of the producer is the choice of the crop to be planted in order to maximize profit. As expenses, the costs of maintaining the plantations are totaled, with the income being the return of the harvests. In the simulation, 10 producers were instantiated, divided into three categories: small size culture - 10 pivots in Rato stream; medium size - 30 pivots in northern Samambaia; and large size - 50 pivots in southern Samambaia.
- Field - represents a central pivot belonging to a Farmer where a crop may be planted (Crop). Each pivot uses water from the river closest to its location in the basin (WaterSource) with consumption determined by its current size and culture, influencing the maintenance cost. In the simulation, it was defined that the same crop cannot be planted in the same pivot twice in a row. This restriction was defined according to field research with farmers in the region [15]. Local farmers follow the technique of crop rotation combined with the direct tillage system to efficiently reduce environmental impacts [43]. These entities are generated from the shapefile mapped by the National Water Agency (ANA) and remain active throughout the simulation.

- Crop - represents a planting culture chosen through field research among the most common crops in the region. Sales price data were obtained from Companhia Nacional de Abastecimento - CONAB (National Company of Supplying $)^{7}$, while data on productivity, cost and time of production were obtained from several sources, the main one being the Instituto para o Fortalecimento da Agropecuária de Goiás - IFAG (Institute for the Strengthening of Agriculture in Goiás) ${ }^{8}$. Each culture has a culture coefficient associated with evapotranspiration in the environment that determines the water demand. This coefficient changes during the life cycle of the crop. In the simulation, four stages with different coefficients were used. The data for determining stages and coefficients were obtained from Monteplan's technical report [44].

- Harvest - represents a harvest cycle from the moment the seeds are planted until harvest. Each entity is associated with a pivot (Field) that is generated at the time of planting and ceases to exist after harvest. A Field has several entities Harvest throughout the simulation.

- WaterSource - represents a water source within the basin associated with sub-basins with a specific flow and total water, providing water to the pivots within your region. These entities are instantiated at the beginning of the simulation and remain active until the end.

To document the described species of the agent-based model, UML (Universal Modeling Language) [45] was used, as shown in the class diagram of Figure 2.

Process overview and scheduling The simulation covers a period of 3 years and 8 months - from January 2016 to August 2019 (44 months) - considering that each month lasts for 30 days. This restriction is due to data available on the CONAB portal, where dates before 2016 presented many gaps and low accuracy.

\footnotetext{
${ }^{7}\langle$ http://sisdep.conab.gov.br/precosiagroweb/〉

${ }^{8}\langle$ http://ifag.org.br $\rangle$
}

\footnotetext{
${ }^{6}\langle$ https://gitlab.com/InfoKnow/MASE/guidodutrasamambaiabasinabms $\rangle$
} 


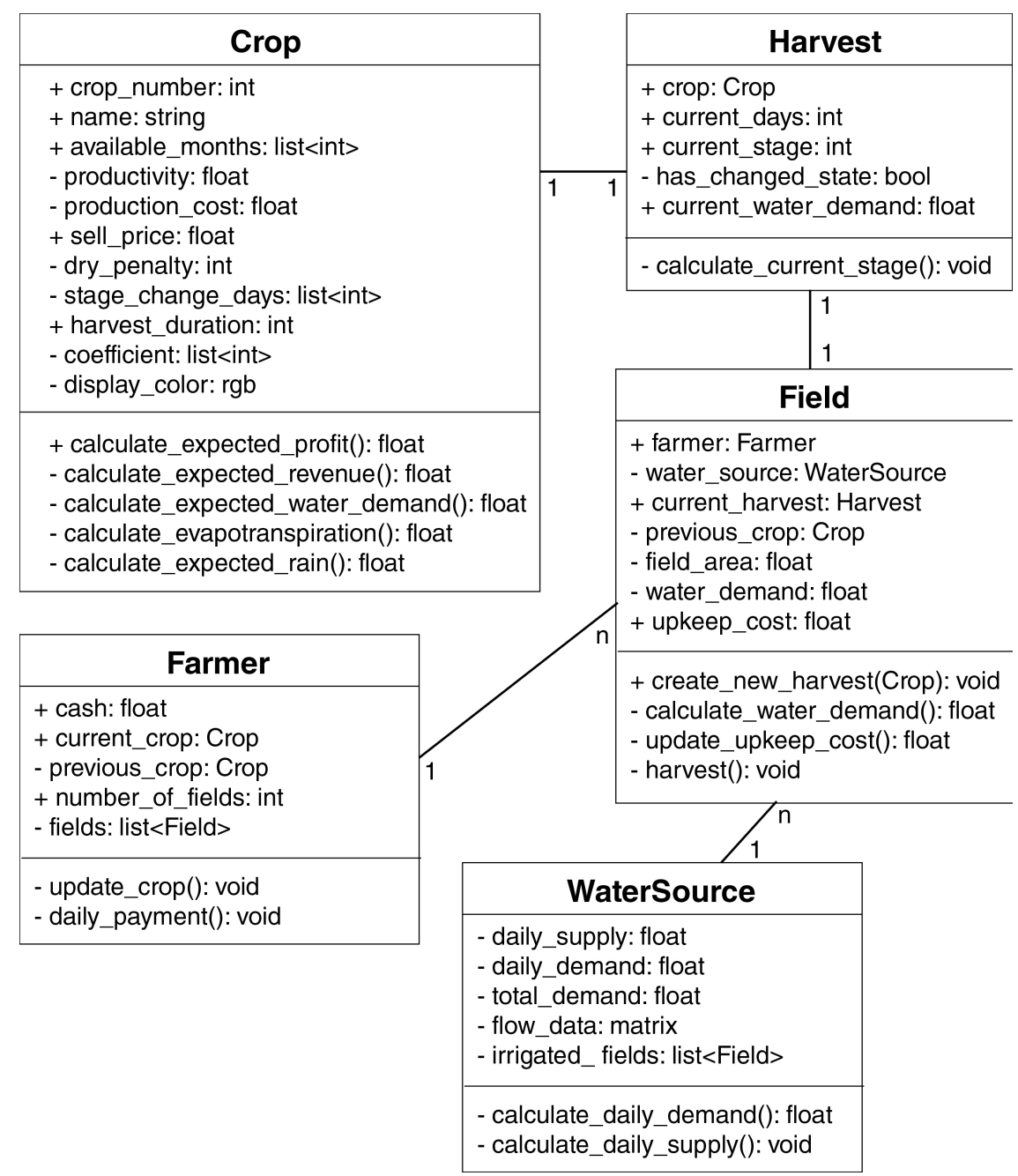

Figure 2. Class diagram of the model.

The simulation resolution is daily. Each simulation iteration is equivalent to one day. The daily updated variables include water demand, crop maintenance costs, farmers' money, precipitation, minimum, average, and maximum temperatures, evapotranspiration. Variables updated monthly include the sale price of crops and the flow of rivers. The daily variables vary according to the crop type (e.g., water demand), while there is no updated information with that frequency for sale price and flow of rivers. The expected financial return for each crop is computed by:

- the maintenance cost $\mathrm{Cm}$ is constant for each crop and it is determined by input data as presented in ODD 3 - Details, input data. For pivots without any culture, a fixed daily cost of $\mathrm{R} \$ 0.01$ was estimated similar to [15].

- the cost of irrigation $C i$ is based on water demand and the influence of rain during the planting cycle. The daily water demand is given by the crop coefficient $C C$ multiplied by the evapotranspiration $e v p$ daily $(C C \times e v p)$. Considering that each crop has four stages in which the $C C$ changes, it is necessary to estimate the water demand for each stage of planting. For this, the evapotranspiration value was considered constant, which is equal to the first day of the stage evp(day1). To calculate the demand for the Dstage and the total demand Dtotal we used

$$
\begin{array}{r}
\text { Dstage }=\operatorname{evp}(\text { day } 1) \times C C \\
\text { Dtotal }=\sum_{n=1}^{4} \text { Dstage }
\end{array}
$$

- to calculate the influence of rain $C$ on water demand, the total rainfall during the planting cycle Ctotal was considered multiplied by the factor $K$ that determines the regularity of rain calculated by

$$
C=\text { Ctotal } \times K
$$

and the total rainfall during the planting cycle Ctotal is computed by

$$
\text { Ctotal }=\text { Cmonth } \times T
$$


where Cmonth is the total amount of rain during the reference month (historical data) and $T$ is the duration of planting in days. The $K$ factor is given by

$$
K=\text { Dabs } /(2 \times \text { Cmonth }), K \subset[0,1[,
$$

where Dabs is the absolute deviation of the historical series during the reference month.

- the profit for each crop $L$ is calculated by

$$
L=P-(C m+C i)
$$

where $P$ is the average selling price for the reference month (harvest month), $\mathrm{Cm}$ is the maintenance cost and $C i$ is the irrigation cost.

- price variability by culture using the variation coefficient $C V$ with the arithmetic mean of the historical series of monthly prices for each crop given by

$$
C V=\frac{\sqrt{\sum\left(x_{i}-\bar{x}\right)^{2} / n}}{\bar{x}},
$$

where $x_{i}=$ individual value, $\bar{x}=$ average values and $n$ $=$ number of values between January 2016 to August 2019 (44 months). If the $C V$ of the most profitable crop is greater than the farmer's tolerance, the second most profitable crop is added, and so on.

- $T$ tolerance to price variability consists of a base value $T b$ and a pivot value $T p$ given by

$$
T=T b+(T p \times N \text { pivos })
$$

where Npivos is the number of pivots that the producer owns. So the more pivots the producer has, the greater his tolerance to price variability and the less simultaneous crops he tends to plant.

The calculation of the producer profit depends on the amount and regularity of rain during the planting period. To model this phenomenon mathematically a precipitation calculation with a normal distribution coefficient is used

$$
k=D / 2 P, k \subset[0,1[
$$

where $D$ is the absolute deviation and $P$ are the total historical precipitation series. The coefficient represents a value of 0 to 1 for rainfall variability, where 0 represents the same amount of rain every day and 1 all rain at a single time. With this coefficient, we estimate the influence of rain on water use as $P \times(1-k)$. Note that the greater the deviation of the series, the greater the coefficient and the lesser the influence of rain, which is equivalent to a scenario in which most of the rain is concentrated in a few days, as occurs in the dry season in the central region of Brazil.

\section{ODD 2 - Design concepts}

Basic principles, emergence, adaptation, objectives, prediction, sensing As a basic principle, we assume that producers seek to maximize their income in an economically sustainable way, through the choice of crops, the availability of water, and other climatic factors that influence this decision. Thus, the water dynamics used in the basin derives from the interaction between economic and hydro-climatic factors.

The main objective of producers is to maximize the financial return even in times of drought. Considering emergence and adaptation, producers change their planting choices depending on the financial return and their income, but once chosen, planting remains constant throughout the simulation.

As a simple prediction, there is the choice of planting by the producers based on the estimate of the profit obtained by culture. For detection, we assume that producers have access to data on temperature, precipitation, and availability of water in the environment.

\section{ODD 3 - Details}

Initialization, Input data, Submodels The simulation starts on 1st January 2016. At this moment, the environment of the basin, the sub-basins, the farmers, and the pivots are generated. The pivots are initially without any planting. For each farmer, one day of the first month is chosen at random to carry out the planting of the first crop.

To start the simulation, input data (shapefiles) obtained from ANA were used including Samanbaia river basin, southern Samambaia, northern Samambaia, and Rato stream basins, mapping of rivers and pivots. Also as input data, we used the market price of crops (CONAB), temperature, and precipitation in the region (Instituto Nacional de Meteorologia INMET) ${ }^{9}$. In addition, water flow in each sub-basin (ANA), crop productivity (multiple sources), time and cost of production (multiple sources) were used as in [15].

There are no submodels in this work. However, due to the GAML language structure, each species is contained in a file that declares a .gaml model as presented in the skeleton of a species file below. In the GAML language, every .gaml file must declare a model, which implies that by design species files are not supported, which would be the equivalent of class files in object-oriented languages. But it is possible to declare model files with only one species (or species that are related by inheritance) and import them into other model files (other species or main model). This was the approach adopted in this work as illustrated in the species file skeleton.

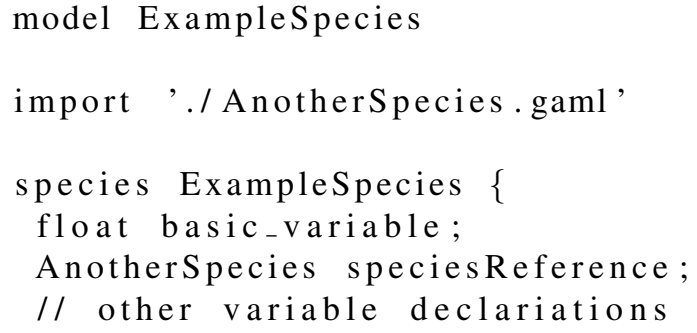

\footnotetext{
${ }^{9}\langle$ http://www.inmet.gov.br/portal/index.php?r=bdmep/bdmep $\rangle$
} 


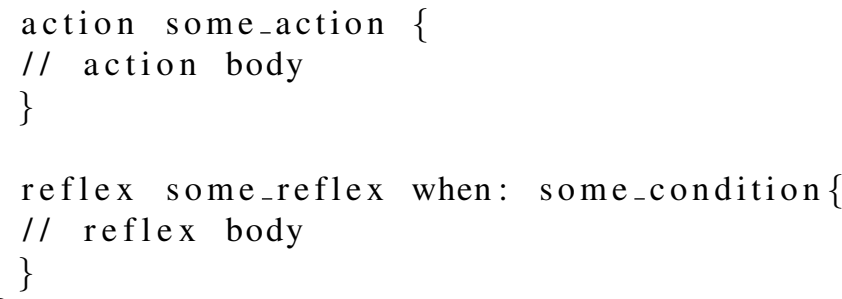

Scope mechanisms and namespaces do not seem to be supported by the GAML language. Nevertheless, it is possible to import files that give access to the entire contents of the file in a global scope. Considering the language requirements we used the following code organization structure:

- separate directories for models, species, experiments, and data;

- a file for the main model;

- global variables declared in the main model file - it is necessary to import the main model in all species files that access global variables;

- one species per file - their species were placed in the same file as their parents.

The project directories structure is presented in Figure 5 using the GAMA platform interface. Figure 6 illustrates the GAMA platform interface using the Samambaia river basin case presented in Section 3.

\section{Case Study}

Most of the area of the Samambaia river basin is located in the municipality of Cristalina in the east of the state of Goiás, in Brazil, taking up a small area of the Federal District. According to [4], the basin covers an area of 88 thousand hectares of which 20 thousand are irrigated by 228 central pivots (Figure 3). There is pressure from producers to increase the irrigated area, but the water supply in the basin is close to the limit, largely due to the use of water in the Batalha hydroelectric plant. The Samambaia river basin was chosen for this work because there is already an initiative between the producers and ANA to implement the collective allocation of water. In addition to the growing trend of expansion of the irrigated area, increasing conflicts as presented in previous works as cited in [15].

The map of the Samambaia river basin is presented in Figure 3 and the map of the pivots in that basin is presented in Figure 4, which is subdivided into three sub-basins (from top to bottom): Rato stream, Samambaia North, and Samambaia South. Each pivot on the map is colored according to the type of cultivation (soy, corn, cotton, beans, potato, garlic, onion, and tomato) and a number that represents the producer to whom this pivot belongs. As mentioned in Section 2, the simulation was instantiated with 10 producers: small with 10 pivots (Rato stream), medium with 30 pivots (northern Samambaia), and large with 50 pivots (southern Samambaia).

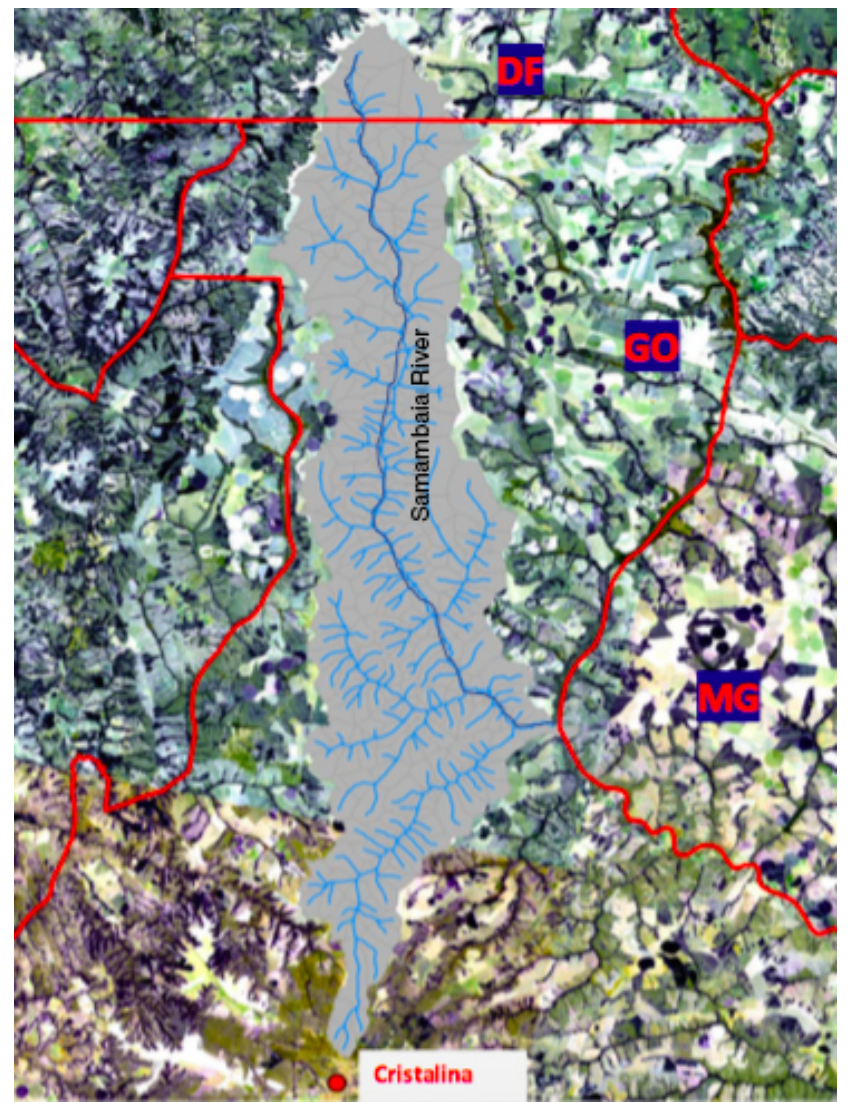

Figure 3. Samambaia river basin map.

Two simulation scenarios were defined: Scenario 1 with the current water grant from ANA and Scenario 2 of water scarcity to verify the influence on the total revenue by culture.

Figure 7 shows the water demand in days considering different periods of the year in the three sub-regions of the basin, as well as the total demand for the Samambaia basin. This figure answers the research question RQ1 (Section 1) considering the simulation period from January 2016 (zero on the X-axis) to August 2019 (1325 on the X-axis). Note that the pattern of water demand is highly variable according to the periods of drought and rain in the region (Y-axis presents the water demand in million liters). Considering that the dry season in the region normally lasts 6.2 months from April 6 to October 13 note that during January the water demand is low due to rains in the region. The top graph presents the Córrego do Rato (Rato stream) varying from 0 to 3.5 million liters, Samambaia Norte (Samambaia North) varying from 0 to 9 million liters, Samambaia Sul (Samambaia South) varying from 0 to 11 million liters and the total varying from 0 to 25 million liters.

Figure 11 answers the research question RQ2 (Section 1) presenting a constant development during time intervals with an increasing pattern in the total assets of producers, represented by wealth in billion of Reais $(\mathrm{R} \$)$ on the Y-axis per time in days on the $\mathrm{X}$-axis. The total assets vary from 0 to $\mathrm{R} \$ 14$ billion. Note that the slope is stable in some parts 


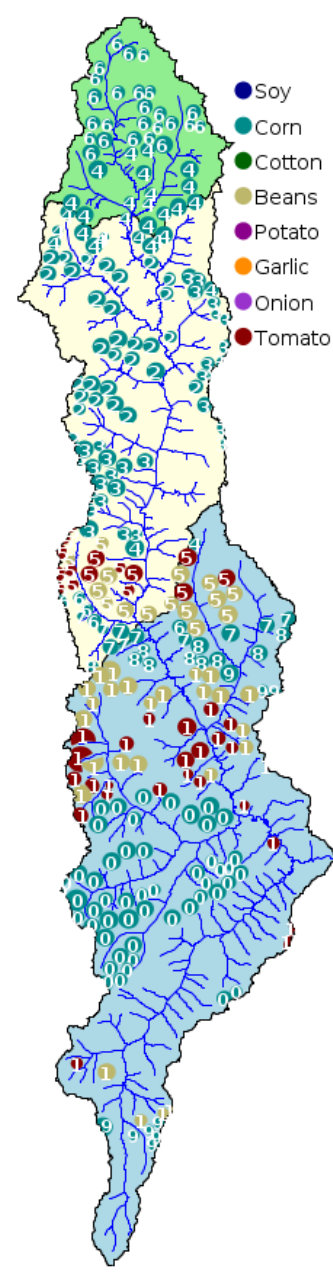

Figure 4. Map of the pivots in the Samambaia river basin.

corresponding to stable equity of the producer category.

Figure 10 presents the wealth distribution per category using pie charts. The left side chart presents the medium producer with 12,221 billion $\mathrm{R} \$$ correspondings to $66 \%$ (blue), the big producer with 4,745 correspondings to $26 \%$ (green), and the small producer with 1,484 correspondings to $8 \%$ (red). The average wealth distribution per producer category (right side pie chart) presents the big producer with 2,372 billion $\mathrm{R} \$$ correspondings to $54 \%$ (green), the medium producer with 1,495 correspondings to $34 \%$ (blue) and the small producer with 0.495 correspondings to $11 \%$ (red). In short, on average the big producer produces $54 \%$ of the total wealth at Samambaia basin ( $\mathrm{R} \$ 14$ billion).

Figures 8 and 9 answer the research question RQ3 considering two different scenarios (Section 1). Scenario 1 considers the current grant of water by ANA [46]. While, the Scenario 2 has water scarcity with $50 \%$ of water reduction.

The (a) in both figures present the total revenue per culture (billion of reais $\mathrm{R} \$$ on the $\mathrm{Y}$-axis) at the top and the production per culture (thousand tons on the Y-axis) considering the production of soy, corn, cotton, beans, potato, garlic, onion and tomato (left to right). The (b) in both figures present in the top part the revenue per culture during the dry period (billion of reais $\mathrm{R} \$$ ) and the bottom part of the production per culture during a period (thousand tons $\mathrm{kg}$ ). It is interesting to note that some crops disappear in the scenario of water scarcity. The tomato crop has the highest production in all scenarios, and the scarcity of water affects over $50 \%$ revenue even without the proportional decrease in production.

As Figure 8 shows total revenue $(\mathrm{R} \$)$ and production $(\mathrm{kg})$ per culture for the total time of the simulation and Figure 9 the same data for a water scarcity scenario, in the simulation the total amount of available water in the basin was multiplied by a parameter $k$, which was set to $0.01(k=0.01)$. But, this parameter can be tweaked in the GUI experiment screen in GAMA.

In the water scarcity scenario (Scenario 2) the production quantity and profitability are significantly different. Although tomato is the most profitable crop in both scenarios, it is relatively less when water is scarce. A similar effect happens for garlic. This result is in line with the field research carried out in [15], where it was reported that garlic is very sensitive to environmental changes, such that a small period with suboptimal conditions may cause a whole harvest to be lost.

Considering the water scarcity scenario (Scenario 2) there is an important restriction that affects the model. During the dry season the water supply exceeds the water demand since we are not considering the water allocated to other activities such as to a nearby hydroelectric plant (Batalha hydropower plant - BHP). The region is simultaneously managed by various agencies and by the Watershed Committee, making it difficult to get aligned water resources management data. Thus, further work must be done to parameterize the simulation to this state. This might be because the real-world water availability for farmers is given not by the total water available in the basin, but by the grant given to them by ANA, which is significantly lower, as water in the basin must be allocated to other activities. There are multiple conflicts caused by water uses described in the literature, but the conflict between hydropower generation and irrigation is an example that there are no references of solution and management success being the subject of further study $[47,48]$.

\section{Discussion}

In this section, we present related work involving agricultural water management applications lightning how the use of agent-based modeling and simulation allows an adequate approach to investigate problems and propose solutions to water resource problems.

In [34] an agent-based simulation is adopted using CORMAS platform [36]. To represent feedback processes between water availability and water use for irrigation, system components related to topography, hydrology, storage, and water use for irrigation are included. The approach was tested for the Jaguaribe basin located in the semi-arid Northeast Brazil. Results present the existence of positive and negative correlations between water availability and water use exist. It was found 


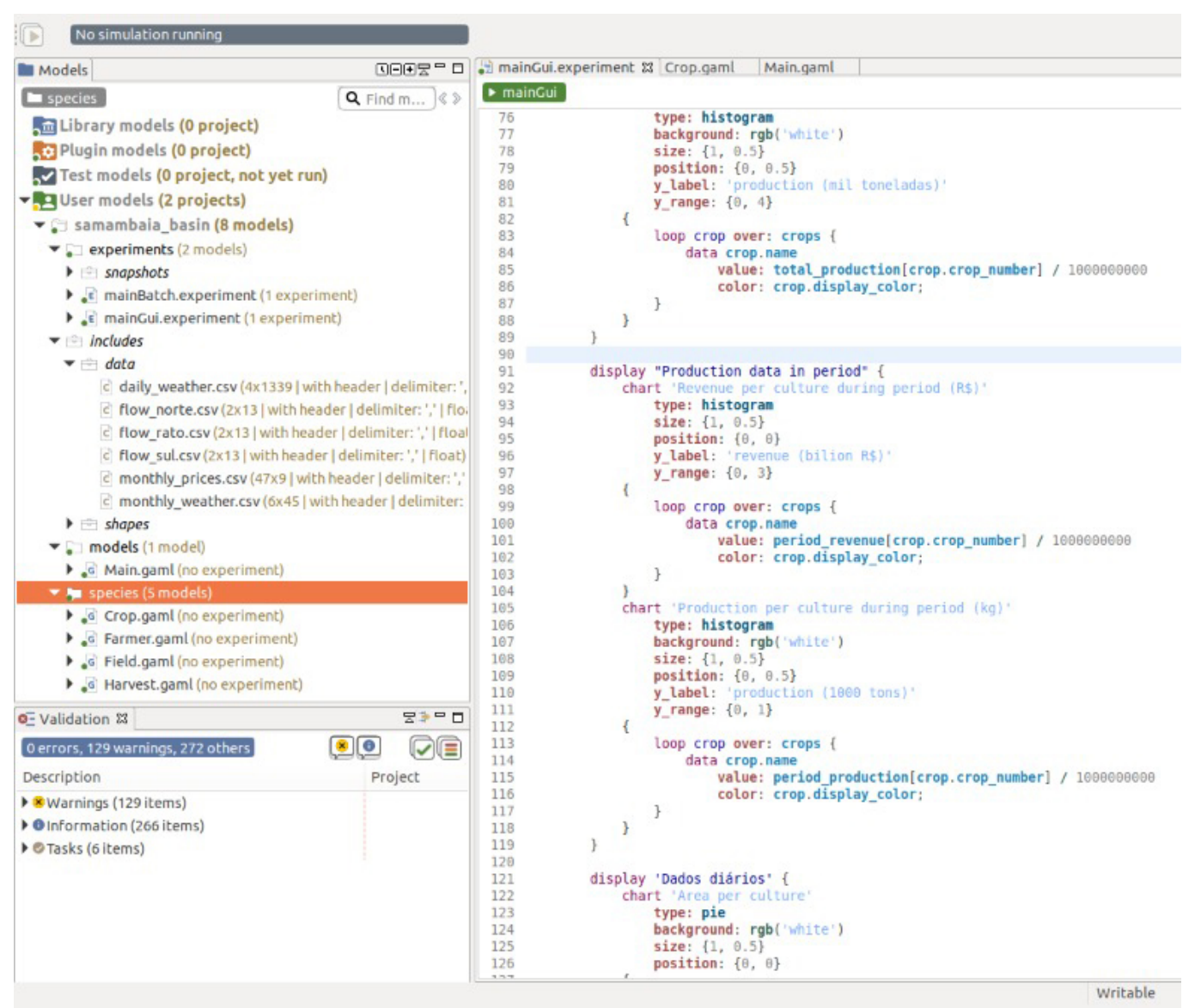

Figure 5. The project structure in GAMA platform.

that increasing wet season water use in times of drought amplifies water stress in the following dry season. Authors conclude that their approach allows representing spatial-temporal variability of water availability that is influenced by water use.

Authors in [27] present the Agent-based Modeling of Resources (Aqua.MORE) platform developed in NetLogo [37]. Aqua.MORE simulates the water resources in a demand and supply system, whereby water fluxes and socioeconomic actors are represented by individual agents that mutually interact and cause complex feedback loops. The platform can support understanding, interpretation, and scenario development of resource flows in coupled human-water systems at the catchment scale. In this article, the authors describe the key steps for developing an agent-based model of water demand and supply using Aqua.MORE and illustrate the modeling process in an idealized Alpine valley, characterized by touristic and agricultural water demand sectors. Authors corroborate the potential of Aqua.MORE as a decision-support tool for sustainable watershed management.

In [32], authors aim to integrate systemic and social complexity aspects proposing a methodological framework $\left(\mathrm{S}^{2} \mathrm{CE}\right)$ for evaluating different alternative actions using the MAELIA multi-agent model [39]. The framework hybridizes an integrated assessment and modeling exercise, with a deliberative multi-criteria evaluation and concludes with a reflexive stage.
Application to agricultural water management illustrates the use of $S^{2} \mathrm{CE}$. The computer simulation was used to enrich collective deliberation by helping stakeholders form and transform their value judgments, and by raising critical questions about options that appeared consensual. The method was applied to a French watershed experiencing ecological crises.

The work of [29] simulated hydrographic basins of São Gonçalo and Lagoa Mirim with georeferenced data for water resources analysis using GAMA platform [40]. Their agentbased model considered agents as regions and rivers where its water can flow among neighbor regions. The authors concluded that each agent significantly interferes in the shared environment. When decision-making is carried out in a participatory manner the involved parties tend to improve their conditions or stay stable in the face of possible problems, but in the opposite situation, most of them achieved great loss or total loss of its production. For future work, the authors cite the definition of a mathematical water flow model for the basin to address real water distribution between the studied regions, water quality, and other environmental impacts.

The water demand increase in the presented Samambaia river basin case drives projects for water management by users born out of partnerships among ANA and the Rural Union of Cristalina (e.g., Samambaia Project). Actions that have not yet been implemented and intend to be included in the project 


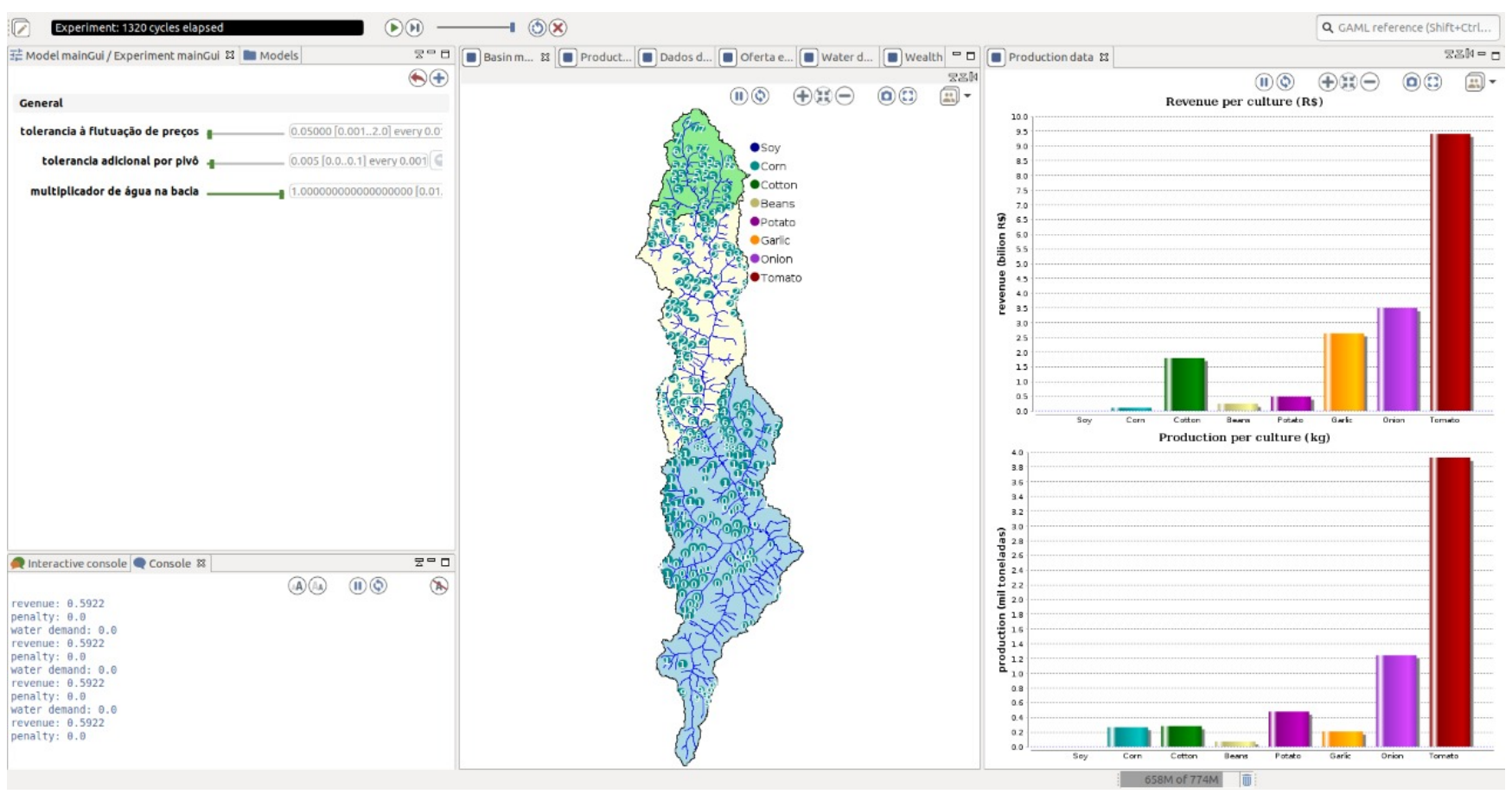

Figure 6. Samambaia river basin case in GAMA platform.

cover the rational use of water for irrigation, organization of irrigators and management-oriented monitoring. Although the presented $\mathrm{ABM}$ is limited, we intend to contribute to ANA's action plan since the simulations reflect the claims of different producers (especially small producers) concerning their productivity allied to the irrigation pivots considering the current grant of water by ANA. Besides, the presented approach can be applied to other critical basins in the country.

\section{Conclusion}

$\mathrm{ABM}$ is applied to simulate a range of water resources engineering disciplines by representing the problems of water users, stakeholders, and decision-makers. Agents can capture decisions and behaviors around water use, water supply, wastewater services, and stormwater runoff. But, there is a gap of works in the literature applying ABM and simulation to agriculture in Brazil. Particularly in large irrigating municipalities in the central-west region of Brazil, one of the main irrigation hubs in the country. This work fulfills this gap developing studies in the Cristalina municipality in Goiás state of Brazil.

In this work, an ABM was developed to simulate the water use for irrigated agriculture by central pivots in the Samambaia river basin located in Cristalina. Three research questions (RQ1, RQ2, and RQ3) related to water demand were answered, generated assets, and revenue by producer category in the various sub-basins of the Samambaia River.

- In RQ1 the water demand for agricultural production in days considering different periods of the year in the three sub-regions of the basin were presented: Córrego do Rato (Rato stream) varying from 0 to 3.5 million liters, Samambaia Norte (Samambaia North) varying from 0 to 9 million liters, Samambaia Sul (Samambaia South) varying from 0 to 11 million liters and the total varying from 0 to 25 million liters.

- The equity generated by producers (RQ2) is presented in Figure 11 with an increasing pattern in the total assets of producers varying from 0 to $\mathrm{R} \$ 14$ billion. Also, in Figure 10, the wealth distribution per producer category is presented using pie charts.

- The influence of water scarcity in the revenue per crop is illustrated by two different scenarios (RQ3) as presented in Figures 8 and 9, with the current grant of water by ANA and with $50 \%$ of water reduction, respectively. The production quantity and profit are significantly different in both scenarios, but for the tomato crop, there is a slight reduction of production with the water reduction, considering that it is one of the productions with the highest financial return.

As future work, we intend to collect historical data on the price of crops and agricultural production in the Samambaia basin to validate the model. Different case studies can be conducted like the semi-arid Northeast of Brazil presented in [34] to highlight more serious problems of scarcity of water resources. The Samambaia river basin case can be developed using the Aqua.MORE platform [27] to evaluate the results as a decision-support tool. Besides, the resulting simulations can be associated with the $\mathrm{S}^{2} \mathrm{CE}$ methodological framework of [32] to integrate systemic and social complexity aspects 

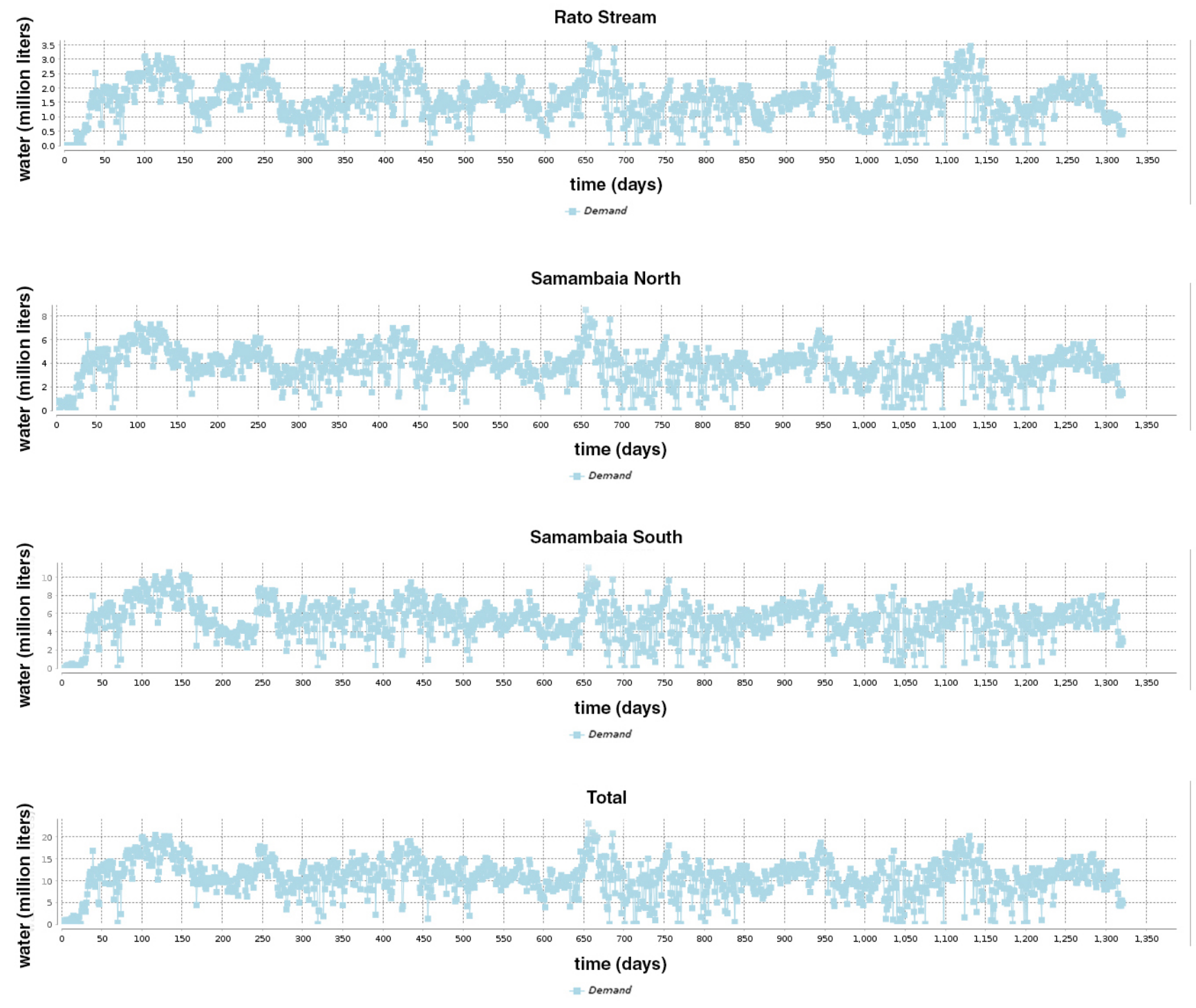

Figure 7. Water demand in the Samambaia basin.

for evaluating different alternative actions for the problem of watershed management. 


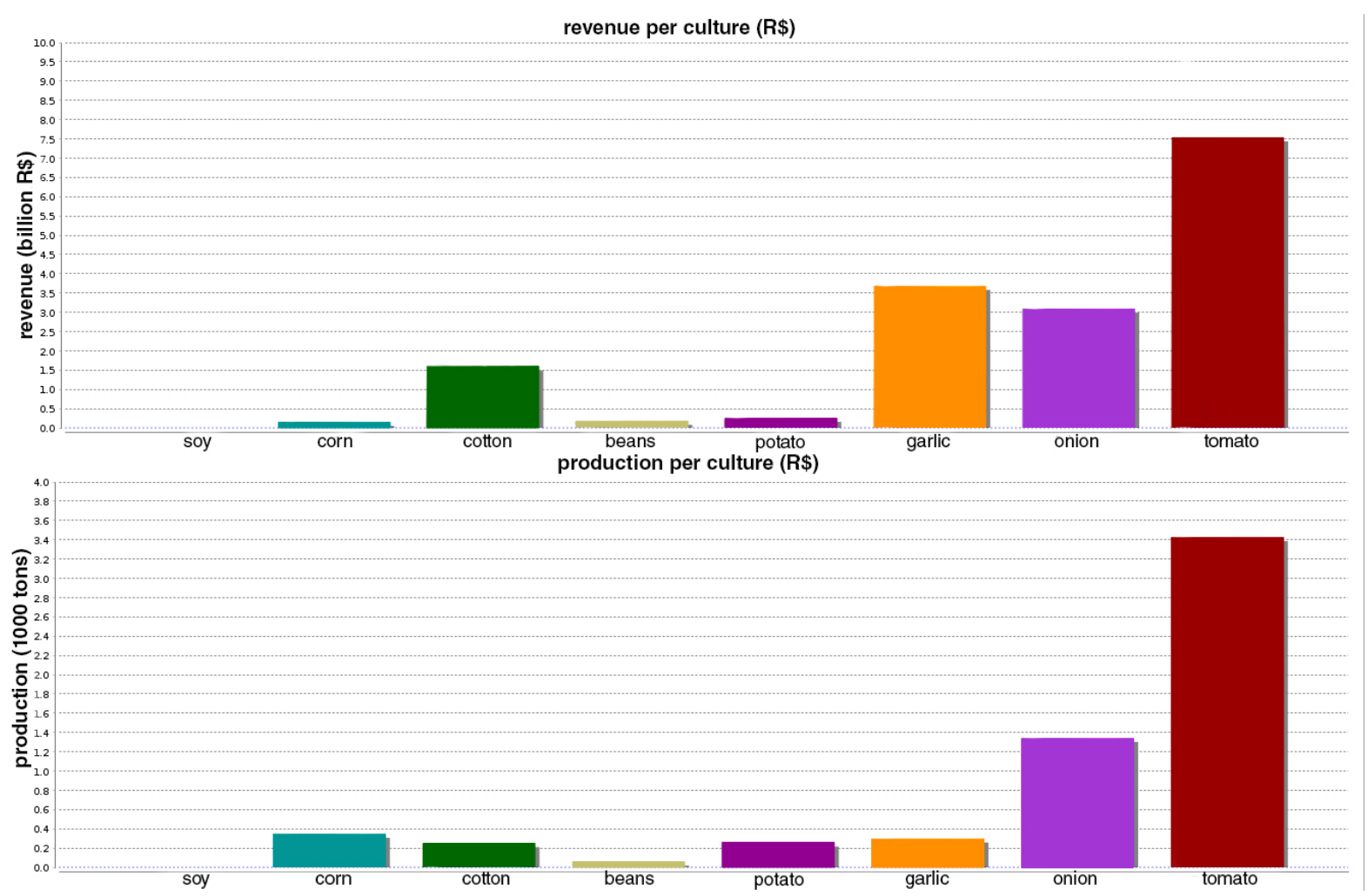

(a)

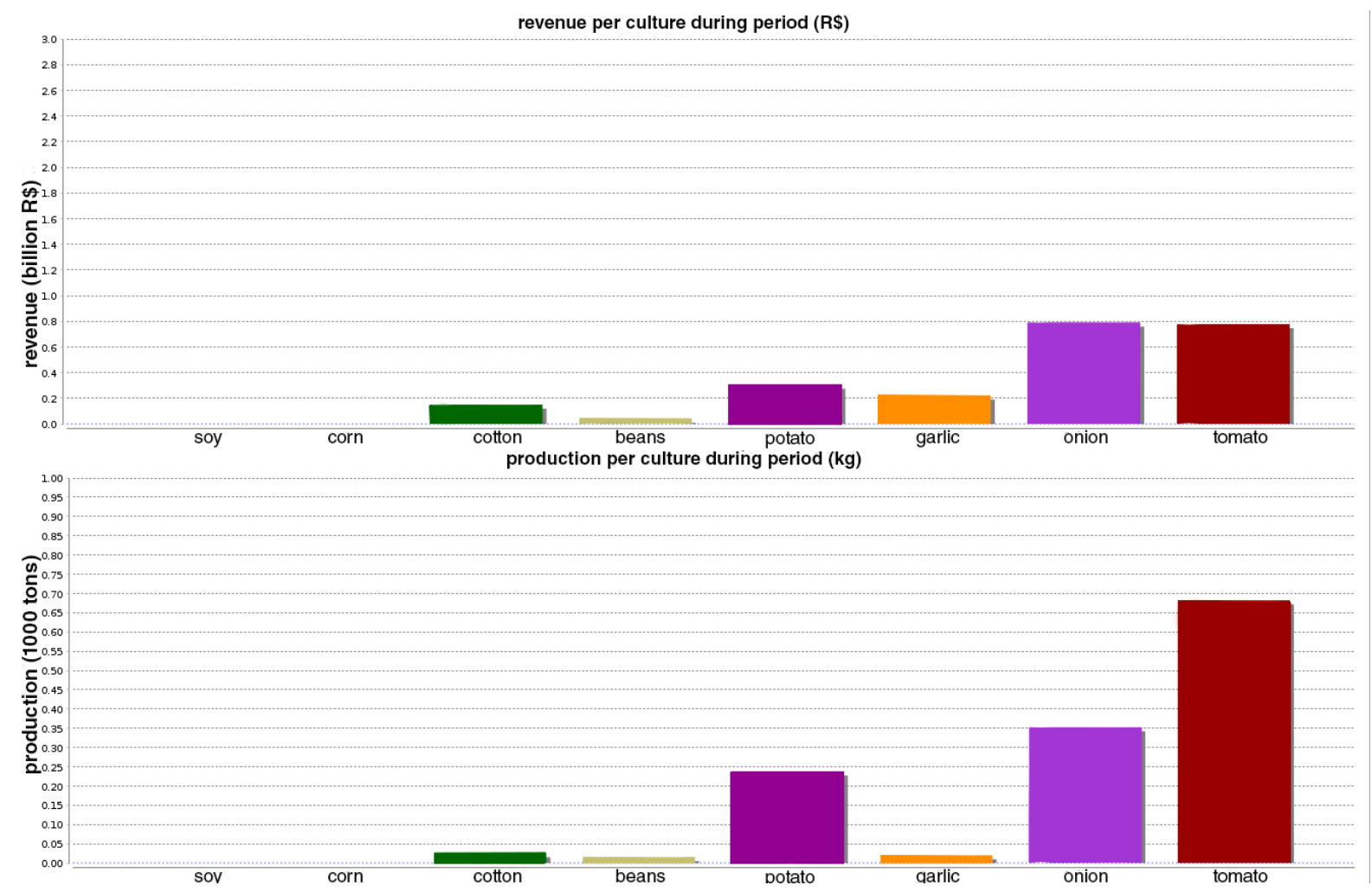

(b)

Figure 8. Data by culture: (a) Total Billing and Production, (b) Dry Billing and Production. 


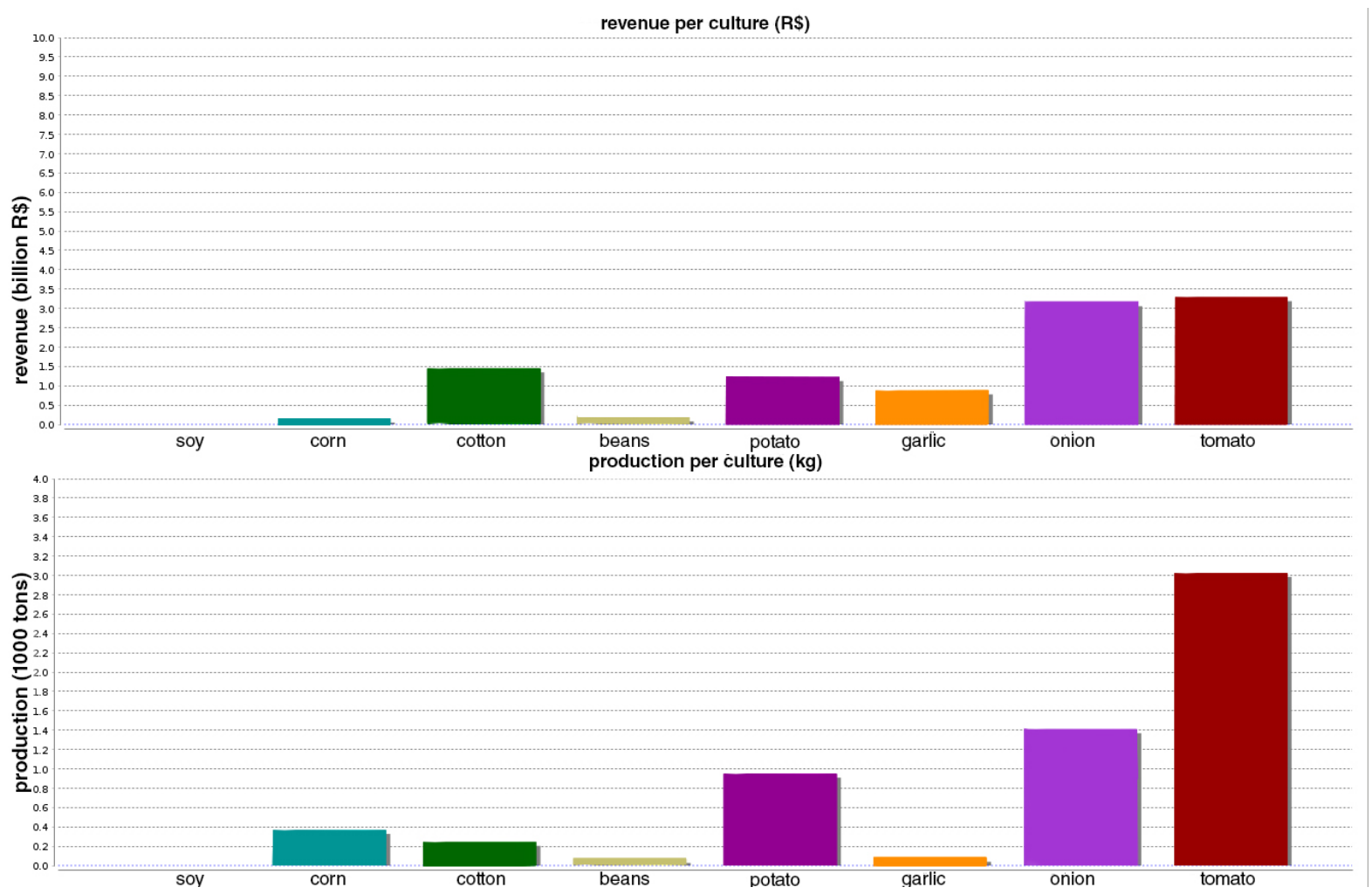

(a)

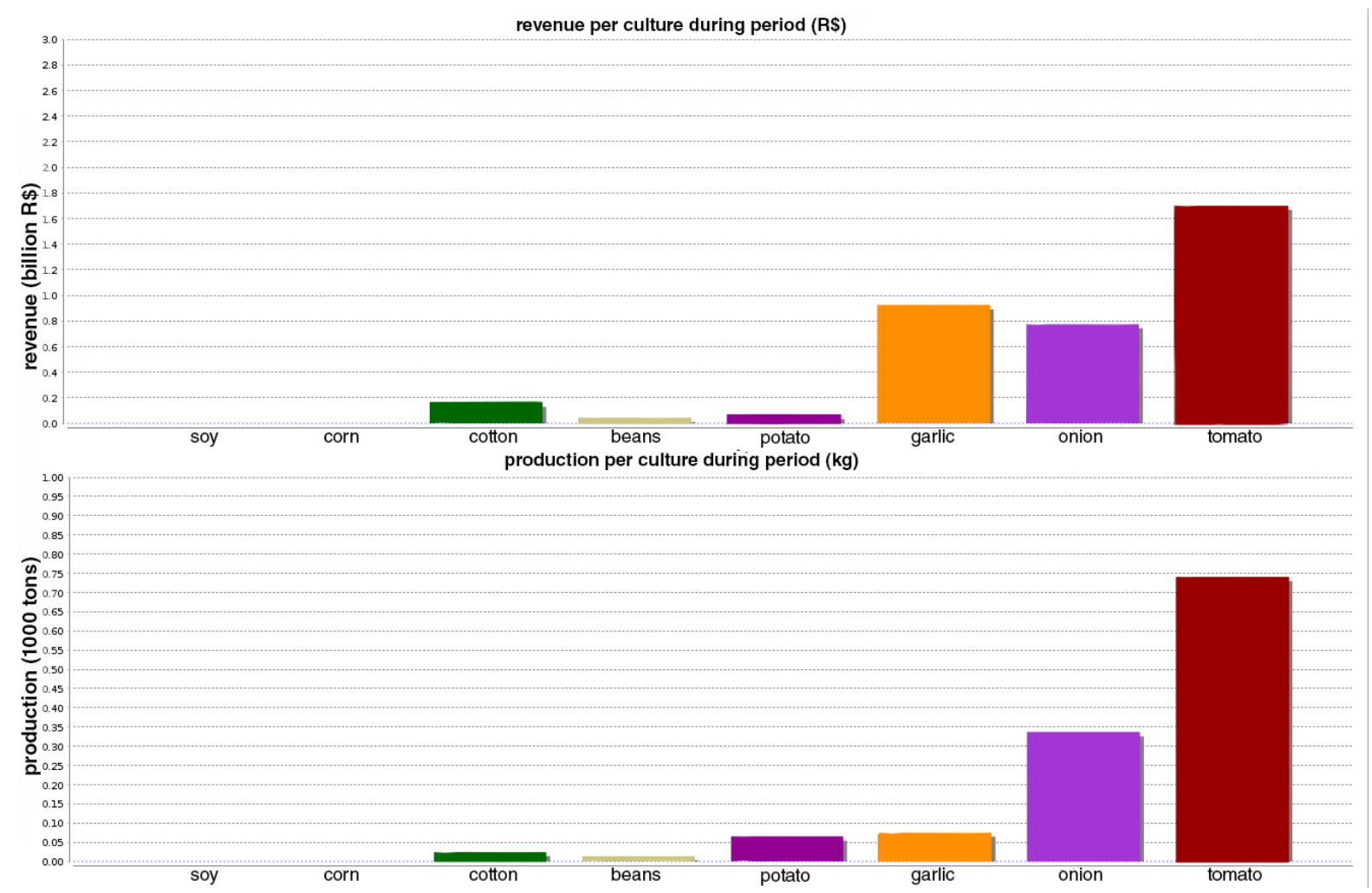

(b)

Figure 9. Data by culture: (a) Total Billing and Production, (b) Dry Billing and Production. 


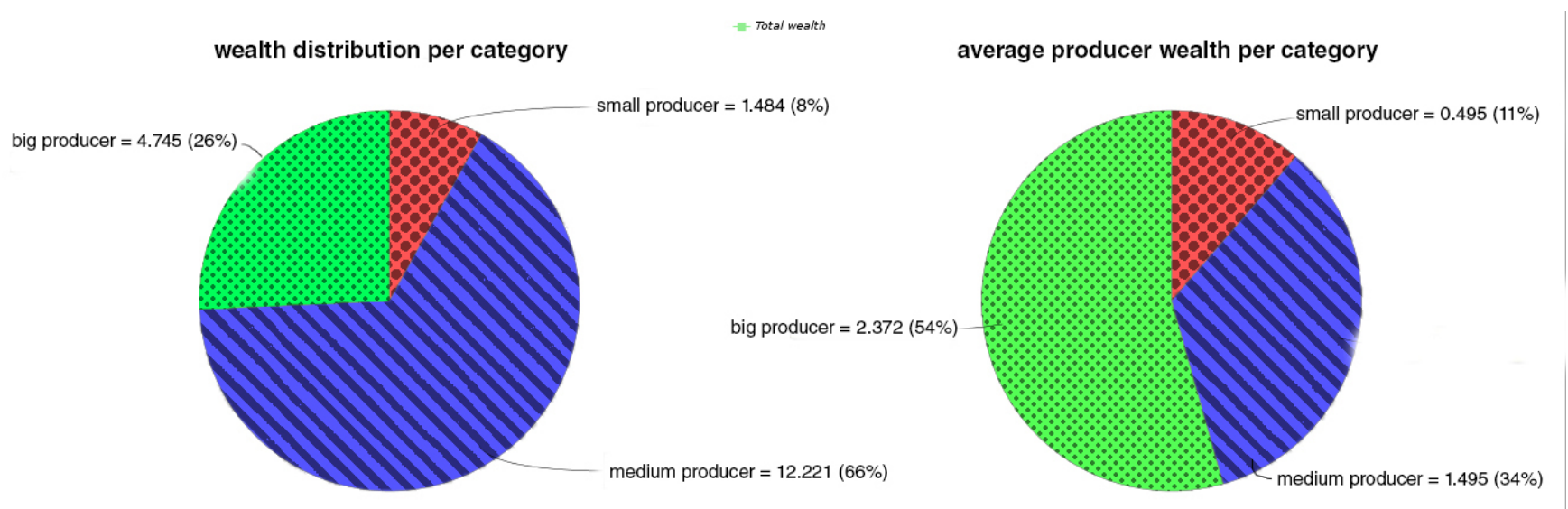

Figure 10. Wealth distribution per producer category.

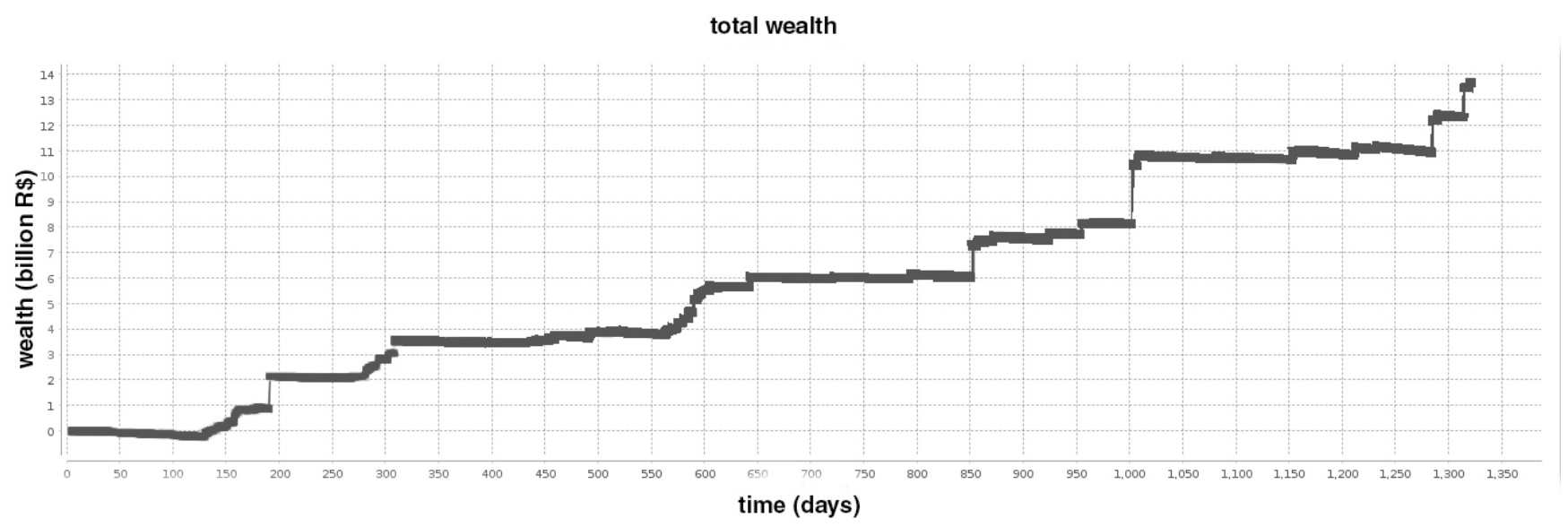

Figure 11. Equity generated by producer category. 


\section{Acknowledgements}

This work was conducted with partial financial support from the National Council for Scientific and Technological Development (CNPq), Brazil, under grant number 311301/2018-5. We thank Celine Ghedini Ralha for improving the quality of the figures.

\section{Author contributions}

All authors contributed to the development of the work considering the discussions about the problem, the modeling, and the development of the simulations. The part related to the implementation on the GAMA platform, both in terms of modeling and in the development of simulations had greater participation by Guido Dutra de Oliveira and Pedro Phelipe Gonçalves Porto, who were supervised by Prof. Célia Ghedini Ralha and Prof. Conceição de Maria Albuquerque Alves, respectively.

\section{References}

[1] EUROPEAN COMMITTEE OF THE REGIONS and LIVING PROSPECTS LTD and PROGRESS CONSULTING S.R.L. Water scarcity and desertification: A survey on the ground analysis result europe $2020 \mathrm{mp}$ survey - the role of regional and local authorities in promoting a sustainable water policy. Luxembourg: EU publications, 2013. Acesso em: 30 de ago. de 2020. Disponível em: 〈http://dx.doi.org/10.2863/ $77141\rangle$.

[2] PETRUZZELLO, M. Water scarcity. Chicago: Encyclopedia Britannica, 2020. Acesso em: 30 de ago. de 2020. Disponível em: 〈https://www.britannica.com/topic/ water-scarcity $\rangle$.

[3] AGÊNCIA NACIONAL DE ÁGUAS E SANEAMENTO BÁSICO. Conjuntura dos recursos hídricos no Brasil 2019: Informe anual. Brasília: Minstério do Desenvolvimento Regional, Governo Federal, Brasil, 2019. Acesso em: 5 de mar. de 2019. Disponível em: 〈http: //conjuntura.ana.gov.br $\rangle$.

[4] AGÊNCIA NACIONAL DE ÁGUAS E SANEAMENTO BÁSICO. Atlas Irrigação: Uso da água na agricultura irrigada. Brasília: Minstério do Desenvolvimento Regional, Governo Federal, Brasil, 2019. Acesso em: 21 de maio de 2019. Disponível em: 〈http://atlasirrigacao.ana.gov.br〉.

[5] ARIS, R. Mathematical Modelling Techniques. Mineola: Dover Publications, 1994. (Dover Books on Computer Science Series).

[6] SAUER, T. Numerical Analysis. 2. ed. Londres: Pearson, 2013. (Pearson Custom Library).

[7] BOYES, W. (Ed.). Instrumentation Reference Book. 3. ed. Oxford: Butterworth Heinemann, 2003.

[8] ZANDBERGEN, P. Python Scripting for ArcGIS. 1. ed. Redlands: ESRI Press, 2013.
[9] REEVES, R. Manual of Remote Sensing. Bethesda: American Society of Photogrammetry, 1975. v. 2. (Manual of Remote Sensing, v. 2).

[10] HUBER, P. J. Robust Statistics. Hoboken: John Wiley \& Sons, 2004. (Wiley Series in Probability and Statistics).

[11] ASQC Task Force and Automotive Industry Action Group. Measurement Systems Analysis: Reference manual. Southfield: Automotive Industry Action Group, 1990. Acesso em: 10 de ago. de 2020. Disponível em: 〈https: //books.google.com.br/books?id=p8kmAQAAMAAJ $\rangle$.

[12] RALHA, C. G. et al. A multi-agent model system for land-use change simulation. Environmental Modelling \& Software, v. 42, p. 30-46, Abril 2013. Disponível em: 〈https: //doi.org/10.1016/j.envsoft.2012.12.003 $\rangle$.

[13] FAN, F. M.; BRAVO, J. M.; COLLISCHONN, W. Modelagem baseada em agentes para a simulação da dispersão de poluentes em cursos d'água. Engenharia Sanitária e Ambiental, Rio de Janeiro, v. 21, n. 4, p. 739-774, 2016.

[14] RALHA, C. G.; ABREU, C. G. Mase: A multi-agentbased environmental simulator. In: ADAMATTI, D. F. (Ed.). Multi-Agent-Based Simulations Applied to Biological and Environmental Systems. Hershey, PA: IGI Global, 2017.

[15] PORTO, P. P. G. Construção de modelo multiagente para avaliação de cenários de manejo de recursos hídricos. Dissertação (Mestrado em Tecnologia Ambiental e Recursos Hídricos) - Universidade de Brasília, Brasília, 2019.

[16] LAW, A. M. Simulation Modeling \& Analysis. 4. ed. New York, NY, USA: McGraw-Hill, 2007.

[17] RICHARDSON, G. P. The Basic Elements of System Dynamics. In: MEYERS, R. A. (Ed.). Complex Systems in Finance and Econometrics. New York: Springer, 2011.

[18] RUBINSTEIN, R. Y.; KROESE, D. P. Simulation and the Monte Carlo Method. 3. ed. Hoboken: Wiley Publishing, 2016.

[19] CELliER, F. E.; KOFMAN, E. Continuous System Simulation. Berlin, Heidelberg: Springer-Verlag, 2006.

[20] MACAL, C. M. Everything you need to know about agent-based modelling and simulation. Journal of Simulation, Taylor \& Francis, Abingdon-on-Thames, v. 10, n. 2, p. 144-156, 2016. Acesso em: 20 de ago. de 2020. Disponível em: 〈https://doi.org/10.1057/jos.2016.7〉.

[21] ALVARES, C. A. et al. Köppen's climate classification map for Brazil. Meteorologische Zeitschrift, Schweizerbart Science Publishers, Stuttgart, Germany, v. 22, n. 6, p. 711728, 12 2013. Acesso em: 18 de nov. de 2020. Disponível em: $\langle$ http://dx.doi.org/10.1127/0941-2948/2013/0507〉.

[22] INSTITUTO BRASILEIRO DE GEOGRAFIA E ESTATÍSTICA. Base de dados: Cidades. Rio de Janeiro: Governo Federal, Brasil, 2019. Acesso em: 20 de abr. de 2019. Disponível em: 〈https://cidades.ibge.gov.br/brasil/go/ cristalina/pesquisa/38/47001?tipo $=$ ranking $\& a n o=2017\rangle$. 
[23] TAILLANDIER, P. et al. Participatory modeling and simulation with the gama platform. Journal of Artificial Societies and Social Simulation, Guildford, v. 22, n. 2, p. 3, 2019. Acesso em: 22 de nov. de 2020. Disponível em: $\langle$ http://jasss.soc.surrey.ac.uk/22/2/3.html $\rangle$.

[24] GRIMM, V.; BERGER, U.; AL. et. A standard protocol for describing individual-based and agent-based models. Ecological Modelling, Elsevier, Amsterdã, v. 198, n. 12, p. 115-126, Setembro de 2006. Disponível em: 〈https: //dx.doi.org/10.1016/j.ecolmodel.2006.04.023〉.

[25] GRIMM, V. et al. The ODD protocol: A review and first update. Ecological Modelling, Elsevier, Amsterdã, v. 221, n. 23 , p. 2760-2768, Novembro de 2010. Disponível em: $\langle$ https://dx.doi.org/10.1016/j.ecolmodel.2010.08.019〉.

[26] BERGLUND, E. Using Agent-Based Modeling for Water Resources Planning and Management. Journal of Water Resources Planning and Management, Reston, v. 141, n. 11, Novembro de 2015. Disponível em: 〈https://doi.org/ 10.1061/(ASCE)WR.1943-5452.0000544〉.

[27] HUBER, L. et al. Agent-based modelling of a coupled water demand and supply system at the catchment scale. Sustainability, v. 11, n. 21, 2019. Special Issue Watershed Modelling and Management for Sustainability. Acesso em: 15 de ago. de 2020. Disponível em: 〈https://doi.org/10.3390/ su11216178>.

[28] HYUN, J.-Y. et al. Using a coupled agent-based modeling approach to analyze the role of risk perception in water management decisions. Hydrology and Earth System Sciences, Göttingen, v. 23, n. 5, p. 2261-2278, 2019. Acesso em: 10 de out. de 2020. Disponível em: 〈https: //hess.copernicus.org/articles/23/2261/2019/>.

[29] FARIAS, G. et al. Water resources analysis: An approach based on agent-based modeling. Revista de Informática Teórica e Aplicada (RITA), Porto Alegre, v. 27, n. 2, 2020. Disponível em: 〈https://doi.org/10.22456/2175-2745.94319〉.

[30] LIN, Z. et al. Using agent-based modeling for water resources management in the bakken region. Journal of Water Resources Planning and Management, Reston, v. 146, n. 1, Janeiro de 2020. Acesso em: 15 de out. de 2020. Disponível em: 〈https://doi.org/10.1061/(ASCE)WR.19435452.0001147〉.

[31] BELAQZIZ, S. et al. An agent based modeling for the gravity irrigation management. Procedia Environmental Sciences, v. 19, p. 804-813, 2013. Four Decades of Progress in Monitoring and Modeling of Processes in the Soil-Plant-Atmosphere System: Applications and Challenges. Acesso em: 10 de set. de 2020. Disponível em: 〈https: //doi.org/10.1016/j.proenv.2013.06.089〉.

[32] ALLAIN, S.; PLUMECOCQ, G.; LEENHARDT, D. Linking deliberative evaluation with integrated assessment and modelling: A methodological framework and its application to agricultural water management. Futures, Am- sterdã, v. 120, p. 102566, 2020. Disponível em: 〈https: //doi.org/10.1016/j.futures.2020.102566〉.

[33] TAMBURINO, L.; BALDASSARRE, G. D.; VICO, G. Water management for irrigation, crop yield and social attitudes: A socio-agricultural agent-based model to explore a collective action problem. Hydrological Sciences Journal, Taylor \& Francis, Rennes Cedex, v. 65, n. 11, p. 18151829, 2020. Acesso em: 10 de out. de 2020. Disponível em: 〈https://doi.org/10.1080/02626667.2020.1769103〉.

[34] VAN OEL, P. R. et al. Feedback mechanisms between water availability and water use in a semi-arid river basin: A spatially explicit multi-agent simulation approach. Environmental Modelling \& Software, v. 25, n. 4, p. 433 443, 2010. Acesso em: 15 de ago. de 2020. Disponível em: $\langle$ https://doi.org/10.1016/j.envsoft.2009.10.018〉.

[35] RURAL, G. Cristalina, em GO, sofre com a falta de chuva e a má distribuição da água. 2017. Acesso em: 20 de nov. de 2020. Disponível em: 〈http://g1.globo.com/economia/ agronegocios/globo-rural/noticia/2017/10/cristalina-em-gosofre-com-falta-de-chuva-e-ma-distribuicao-da-agua.html $\rangle$.

[36] BOUSQUET, F. et al. Cormas: Common-pool resources and multi-agent systems. In: POBIL, A. Pasqual del; MIRA, J.; ALI, M. (Ed.). Tasks and Methods in Applied Artificial Intelligence. Berlim: Springer, 1998. p. 826-837.

[37] WILENSKY, U.; RAND, W. An introduction to agentbased modeling: Modeling natural, social and engineered complex systems with netlogo. Cambridge, MA, USA: MIT Press, 2015.

[38] NORTH, M. J. et al. Complex adaptive systems modeling with repast simphony. Complex Adaptive Systems Modeling, Berlim, v. 1, p. artigo n. 3, Março de 2013. Acesso em: 10 de ago. de 2020. Disponível em: 〈https: //doi.org/10.1186/2194-3206-1-3〉.

[39] GAUDOU, B. et al. The MAELIA multi-agent platform for integrated analysis of interactions between agricultural land-use and low-water management strategies. In: ALAM, S. J.; PARUNAK, H. V. D. (Ed.). XIV International Workshop on Multi-Agent-Based Simulation (MABS). Berlim: Springer, 2014. p. 85-100.

[40] TAILLANDIER, P. et al. Building, composing and experimenting complex spatial models with the gama platform. Geoinformatica, Springer Science+Business Media, LLC, part of Springer Nature, Berlim, v. 23, p. 299-322, 2019. Acesso em: 15 de ago. de 2020. Disponível em: 〈https://doi.org/10.1007/s10707-018-00339-6〉.

[41] VOINOV, A.; BOUSQUET, F. Modelling with stakeholders. Environmental Modelling \& Software, v. 25, n. 11, p. 1268-1281, 2010. Thematic Issue - Modelling with Stakeholders. Acesso em: 20 de nov. de 2020. Disponível em: 〈http://www.sciencedirect.com/science/ article/pii/S1364815210000538〉. 
[42] TAILLANDIER, F.; ADAM, C. Games ready to use: A serious game for teaching natural risk management. Simulation \& Gaming, Thousand Oaks, v. 49, n. 4, p. 441470, 2018. Acesso em: de 19 nov. de 2020. Disponível em: $\langle$ https://doi.org/10.1177/1046878118770217〉.

[43] DENARDIN, J. E. et al. Diretrizes do sistema plantio direto no contexto da agricultura conservacionista. Passo Fundo: Embrapa Trigo, 2012. Acesso em: 30 de ago. de 2020. Disponível em: 〈http://www.cnpt.embrapa.br/biblio/ do/p_do141.htm $\rangle$.

[44] MONTEPLAN; IRRIGO. Relatório Técnico, Análise da Resolução ANA 562/2010: Marco Regulatório Rio São Marcos. Cristalina - GO. Fortaleza: [s.n.], 2011. Disponível em: 〈https://www.gov.br/ana/pt-br/todos-os-documentos-doportal/documentos-sre/marcos-regulatorios/562-2010.pdf $>$.

[45] BOOCH, G.; RUMBAUGH, J.; JACOBSON, I. Unified
Modeling Language User Guide. 2. ed. Boston: AddisonWesley, 2005.

[46] AGÊNCIA NACIONAL DE ÁGUAS. Nota Técnica $\mathbf{n}^{\mathbf{0}}$ 132/2010/GEREG/SOF-ANA. Brasília: Ministério de Desenvolvimento Regional, Governo Federal, Brasil, 2010.

[47] SILVA, L. M. da C.; HORA, M. de A. G. M. da. Conflito pelo Uso da Água na Bacia Hidrográfica do Rio São Marcos: O Estudo de Caso da UHE Batalha. ENGEVISTA, Rio de Janeiro, v. 17, n. 2, p. 166-174, Junho de 2015.

[48] SOUSA, V. C. M. A questão agrária e os conflitos pelo uso da Água dentro de uma perspectiva da teoria crítica dos direitos humanos. Revista de Direito Agrário e Agroambiental, v. 4, n. 1, 2018. Acesso em: 10 de nov. de 2020. Disponível em: 〈http://dx.doi.org/10.26668/ IndexLawJournals/2526-0081/2018.v4i1.4357〉. 